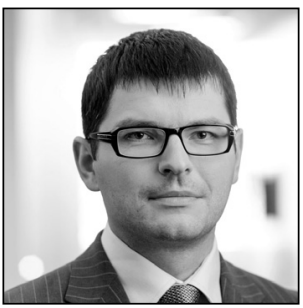

Leonid Tolstov

Attorney-at-Law

Partner, Law Office VARUL

\title{
Personal Liability of a Director to Creditors in the Case of Thin Capitalisation of a Company
}

\section{Introduction}

The foundation of a limited-liability capital company ${ }^{*}$ is its capital, and the concept of limited liability proceeds from this fact. ${ }^{{ }_{2}}$ As shareholders of a company are liable for that company's debts to the amount of capital paid up, it is important for the creditors that the company retain its capital, since, in the event that the company's capital is used up, the unsecured claims of creditors remain partially or completely noncovered. When a company's capital falls below the statutory limit (a situation known as thin capitalisation), the company enters a hazard zone. This can be considered to be a pre-insolvency situation. ${ }^{*} 3$

It is generally recognised that a company director ${ }^{*} 4$ is not liable to the creditors of the company and, as a rule, has duties only to the company. ${ }^{*}{ }^{*}$ However, the situation changes when the company becomes

1 The most common types of companies with capital are the GmbH (for the German 'Gesellschaft mit begrenzter Haftung') type of company, a form of company intended mainly for small and medium-sized entities, and the AG-type company (the Aktiengesellschaft form, again as seen in Germany), meant primarily for large companies. The article deals mostly with the liability of directors of a GmbH-type limited-liability company since that type of company is the most widespread and, therefore, associated liability cases too are seen more often. For further explanation, in the countries analysed in the article, counterparts of the GmbH are Spain's 'Sociedad de responsabilidad limitada' (or 'S.R.L.'), the 'private limited company' (abbreviated 'Ltd' in the company's name) found in the United Kingdom, and the osaühing in Estonia (abbreviated 'OÜ'). The AG-type companies are considered in the article in relation to matters that are in principle regulated differently than for GmbH-type companies. In the countries analysed in the article, counterparts of the AG are Spain's 'Sociedad Anónima' (or 'S.A.'), the United Kingdom's 'public limited company' (or 'Plc'), and Estonia's aktsiaselts (abbreviated 'AS').

2 On the limited liability of shareholders of a company, see T. Raiser, R. Veil. Recht der Kapitalgesellschaften. ['Corporate Law'], Verlag Franz Vahlen 2010, p. $327 \mathrm{ff}$. (in German).

3 It is difficult to determine the pre-insolvency situation precisely since, at base, any kind of situation that precedes insolvency could be considered to be a pre-insolvency situation. In general, it is possible to speak of the pre-insolvency situation when the regular economic activities of a company are in a crisis but the problems that have arisen have not become irreversible and permanent yet. In the context of this article, the pre-insolvency situation of a company is limited to thin capitalisation when the company's capital has fallen below the minimum statutory limit but the company has not become permanently insolvent yet.

4 To explain the term used: in countries studied in the article, it is stated here that the counterparts of the well-known 'director' found in English law are the Geschäftsführer in a GmbH or Vorstandsmitglied in an AG in Germany, the administrador in Spain, and a juhatuse liige (member of the management board) in Estonia. For greater readability, the term 'director' is used throughout the article.

5 Breach of a director's duties in a case of thin capitalisation may bring about the director's internal liability to the company. However, this issue remains beyond the scope of the present article. For more information about a director's internal liability in a case of thin capitalisation, see R. Bork, C. Schäfer. Kommentar zum GmbH-Gesetz, 2nd ed. RWS Verlag Kommunikationsforum 2012, p. 974. 
insolvent, because by that time the company has used up its capital and further activities are possible only through the use of loan capital. This is why many countries have prescribed an obligation for the director to terminate the company's activities in the event of the company's insolvency. If that obligation is violated, the director may be held personally liable for partial or full compensation of creditors' outstanding claims. ${ }^{* 6}$

The purpose of this article is to analyse, on the basis of German, English, Spanish, and Estonian law, whether personal liability of a director for damaging the interests of creditors could be applied earlier, in a phase preceding insolvency-when the company's capital has not been entirely used up but the company has already reached the stage of thin capitalisation and may become permanently insolvent. From the perspective of a director's civil liability, the important question is how much business risk the director should be allowed to take when managing a company that is experiencing thin capitalisation and when (and under what circumstances) the director should be held personally liable to the creditors of the company.

\section{Capital requirements applied to companies}

The fixed capital of a company is the initial capital specified by law or the articles of association and paid up by shareholders. It forms the basis for credit for a company and serves the interests of securing the creditors' claims. ${ }^{*}$ The minimum capital requirements in the countries considered in the present article vary considerably. For example, German law states that the amount of minimum capital of a GmbH-type company is EUR 25, $\mathrm{OOO}^{*}$; ; wile the minimum capital of an S.R.L.-type company in Spain, a corresponding form of company, is EUR 3,000 ${ }^{*} 9$ and that of an OÜ-form company in Estonia is EUR 2,500 ${ }^{* 10}$. However, an 'Ltd' incorporated in England can be created with any number of shares, of any value, while the Companies Act 2006 (or 'CA 2006'), in Subsection 763 (1), establishes a requirement as to the minimum share capital of a 'Plc', which is $£ 50,000 .{ }^{*} 11$

It is clear that one important feature of a limited-liability company (or capital company) is a minimum amount of capital set forth by law or in the articles of association. Since the principle of limited liability of a capital company is tied directly to the company's capital, it is extremely important to guarantee maintenance of capital at least to its specified minimal extent in order to ensure solid economic circulation and protect the interests of creditors.

Since the management board is entrusted with day-to-day management of the company and organisation of its accounting, compliance with capital requirements is dependent on, above all, the acts and omissions of the director. Article 17 of the EU's Second Company Law Directive ${ }^{* 12}$ imposes a duty to call a

6 For example, in Germany the director has an obligation to submit a bankruptcy petition when the company has become permanently insolvent. With this, the director subjects the subsequent existence of the company to a court's and bankruptcy trustee surveillance and prevents further decrease in the company's capital. In the United Kingdom, the director has no direct obligation to submit a bankruptcy petition; however, a similar result is achieved by prescription of liability of the director for wrongful trading when the director damages the interests of creditors by continuing the economic activities of the company in circumstances wherein it is evident that it is not possible to prevent the company's insolvency and liquidation any longer. For comparative material on protection of the interests of creditors in the event of a company's insolvency in German and English law, see C. Thole. Gläubigerschutz durch Insolvenzrecht. Mohr Siebeck 2010.

$7 \quad$ T. Raiser, R. Veil (see Note 3), p. 328.

8 Article 5 (1) of the GmbH Act (in German, known as das GmbH-Gesetz). Available at http://www.gesetze-im-internet.de/ gmbhg/__ $5 \cdot$ html (most recently accessed on 6.1.2014) (in German).

9 Article 4 (1) of the Spanish Companies Act (in Spanish, called the Texto Refundido de la Ley de Sociedades de Capital). Available at http://noticias.juridicas.com/base_datos/Privado/rdleg1-2010.t1.html\#a4 (most recently accessed on 6.1.2014) (in Spanish).

10 Section 136 of the Estonian Commercial Code (in Estonian, the äriseadustik). - RT I 1995, 26/28, 355; RT I 2005, 63,481 (in Estonian). English text is available via http://www.legaltext.ee/ (most recently accessed on 1.1.2014). In the countries referred to, it is also possible to establish companies with less capital or without paying up the capital under certain circumstances; however, that does not, in its essence, affect the issue of thin capitalisation and, therefore, the author will not analyse the issue more thoroughly at this point.

11 For comparison purposes, the minimum capital for a German AG is EUR 50,000, the minimum capital for a Spanish S.A. is EUR 60,000, and the minimum capital for an Estonian AS is EUR 25,000.

12 Council Directive 77/91/EEC, of 13 December 1976, on the co-ordination of safeguards that, for the protection of the interests of members and others, are required by Member States from companies within the meaning of the second paragraph of Article 58 of the establishing treaty, in respect of the formation of public limited-liability companies and the maintenance and alteration of their capital, with a view to making such safeguards equivalent - [1977] OJ L 026/ooo1. 
meeting if more than half of the subscribed capital is lost. In addition, this principle is integrated into the national regulations of all the countries examined here.

However, a question always follows a provision that prescribes a duty-what will be the consequences for violating that duty?

With the countries studied, it is remarkable that the duties of the director in the case of thin capitalisation are, in large part, limited to only the obligation to call a general meeting. Since this obligation is quite a formal one, it is difficult to implement civil liability of the director if that duty is violated, and several legislators have tried to resolve the situation through threats of criminal sanctions. ${ }^{*} 13$ This author is of the opinion that applying criminal penalties in the given case involves overreacting with the coercive measures of the state. ${ }^{* 14}$ Therefore, a question that might be of interest is whether it would be possible to resolve the matter of the liability of the director through civil law just as well.

In the next section of the paper, the author will explain whether, in a parallel to breach of a director's duties in a situation of insolvency ${ }^{* 1}$, it would be possible and practical to implement civil liability of primarily the director in the event of thin capitalisation if, from the standpoint of creditors, it were possible to file a tortious claim directly against the director. This would enable enforcement of creditors' claims toward the director to a much larger extent, which, in turn, would impel the director to apply measures earlier in order to avoid using up the available loan capital.

\section{The possibility of a director's civil liability in the event of failure to call a general meeting in a case of thin capitalisation}

According to $\$ 49$ (3) of the German GmbH Act, the director is obliged to call a general meeting of the company if it has become evident that half of the fixed capital of the company is lost-that is, if the net assets of the company do not cover at least half of the statutory share capital. ${ }^{*}{ }^{16}$ The purpose of the provision mentioned is to protect the investments of the company and its shareholders while also allowing decisionmaking about the company's future and, through that, indirectly protecting the interests of creditors, since effective crisis management would surely be in their interest. ${ }^{*} 17$

According to German authors, the direct protective purpose of $\$ 49$ (3) of the GmbH Act is the protection of shareholders. The intent of the regulation is to make the shareholders aware of the crisis situation of the company and enable them to adopt timely countermeasures, which would also assist in the satisfying of creditors' claims. ${ }^{*} 18$ However, the interests of creditors can only be taken into consideration indirectly,

13 In Germany, according to $\S 84$ of the GmbH Act, a director may be punished with a pecuniary penalty or up to three years' imprisonment for not notifying shareholders of a decrease in capital. The English CA 2006, in its Subsection 656 (5), limits the punishment to a fine. The relevant portion of CA 2006 is available at http://www.legislation.gov.uk/ukpga/2006/46/ section/656 (most recently accessed on 6.1.2014).

14 For example, the Estonian legislator intends to repeal $\$ 380$ of the Estonian Penal Code, which specifies criminal sanctions for the breach of the director's duties in the case of thin capitalisation. See the draft for amendments to the Estonian Penal Code and related legal acts as available at http://www.riigikogu.ee/?page=eelnou\&op=ems\&eid=78433b298b2f-4281-a582-oefb9631e2ad (most recently accessed on 6.1.2014) (in Estonian).

15 If a director fails to submit a bankruptcy petition in a situation of insolvency, that director may be held personally liable in all countries considered in this article (in Germany, this is addressed in §15a of the Insolvency Act (in German, known as the Insolvenzordnung, or the InsO) and in $\$ 823$ (2) of the Civil Code (in German, the Bürgerliches Gesetzbuch, or the BGB); in Spain, it is set forth in Articles 5 and 172 bis (1) of the Insolvency Act (in Spanish, the Ley Concursal); and it is covered in Estonia by $\S 180\left(5^{1}\right)$ of the Commercial Code and $\$ 1045$ (1) (7) of the Law of Obligations Act, or LOA (in Estonian, the Võlaõigusseadus)). The same applies if the director continues the economic activities of a company with hopeless prospects for the future in England (under the Insolvency Act 1986, Section 214).

16 R. Jula. Der GmbH-Geschäftsführer. ['Director of a GmbH Company'], 4th ed. Springer 2012, p. 152 (in German).

17 M. Lutter et al. GmbH-Gesetz, Kommentar, 18th ed. Verlag Otto Schmidt 2012, pp. 1318, 1319 - DOI: http://dx.doi. org/10.9785/ovs.9783504380236; K. Schmidt, W. Uhlenbruck. Die GmbH in Krise, Sanierung und Insolvenz. ['GmbH Company in Crisis, Safeguard and Bankruptcy'], 3rd ed. Verlag Dr Otto Schmidt 2003, p. 21.

18 M. Lutter et al. (see Note 18), p. 1321 - DOI: http://dx.doi.org/10.9785/ovs.9783504380236; G. Crezelius et al. Scholz Kommentar zum GmbH-Gesetz. ['Scholz Commentary of the GmbH Act'], 9th ed, Vol. 2. Verlag Dr Otto Schmidt 2002, p. 2586; L. Michalski et al. Kommentar zum Gesetz betreffend die Gesellschaften mit beschränkter Haftung (GmbH-Gesetz), Vol. 2. C.H. Beck 2002, pp. 1025-1026 (in German). 
through it being rendered less probable that the company will 'go bust'. Breach of the director's duty to call a general meeting of the shareholders is punishable pursuant to criminal procedure by up to three years of imprisonment ${ }^{*}{ }^{*}$, but it is not possible for creditors to file a tortious claim against the director if the director fails to call a meeting.

As has already been mentioned, the English 'Ltd' has no minimum capital requirements, which is why thin capitalisation of a limited company in this context cannot formally take place. ${ }^{*}{ }^{20}$ Regarding the English 'Plc', Section 656 of the CA 2006 stipulates the director's obligation to call a general meeting, similarly to what is done in German law. Indeed, one could discuss in English law as well whether the protective purpose, here of Section 656 of the CA 2006, might be the protection of creditors. Although not an absolute rule, it proceeds from the assumption in England that if the obligation stipulated in a provision of the law is already sanctioned with a public-law punishment, then the will of the legislator has been expressed and additional tortious liability for breach of statutory duty is not possible. ${ }^{{ }^{21}}$ According to the CA 2006, in Subsection 656 (5), a person who is guilty of an offence under this section of law is liable for a fine. ${ }^{{ }^{2} 2}$ Pursuant to CA 2006, Section 656, the creditors may not file a tortious claim against the director on the basis of either law or judicial practice. ${ }^{* 23}$ Therefore, it is possible to say that civil liability of a director to creditors that results from thin capitalisation of a company is not implemented in English law either.

Under Estonian law, the director is obliged to call a general meeting of the company, in a parallel to English and German law, when that company experiences thin capitalisation. No direct civil sanctions arise from the law in the event that the above-mentioned duty is violated. As in German law, it would be reasonable to ask in the context of this article whether the provision that stipulates the duty to call a general meeting in cases of thin capitalisation of a company could be handled as a protective provision the violation of which could result in tortious liability of a director to creditors.

At first glance, it may be tempting to compare the duty in question with the obligation to file a bankruptcy petition; the provisions stipulating the latter obligation have been considered by courts to be indisputably protective provisions that protect the creditors. ${ }^{*} 24$ At the same time, however, the situations of thin capitalisation and permanent insolvency are still different and looking at them as equal would not be correct. Although thin capitalisation of a company may be a sign of threat with respect to the company's solvency, it does not always mean that the company is going to become insolvent. Fulfilment of the director's duty to call a general meeting does not automatically protect the creditors. Calling of a general meeting only serves as a prerequisite to shareholders taking decisions that may indirectly protect the interests of the creditors too. In a contrast to the Spanish law as analysed below, in Estonia the director has no additional duty (that would protect the creditors) if the shareholders fail to act. For example, if the director calls a general meeting as is required yet the shareholders refuse to take any kind of decision, the director has, fundamentally, fulfilled his duty and may continue the economic activities of the company at least until the company becomes permanently insolvent. This is what distinguishes the situation significantly from that of the duty to file a bankruptcy petition-when a bankruptcy petition is filed as required, further decrease of assets will be suspended in the interests of the creditors; however, calling a general meeting in a case of thin capitalisation may influence the interests of creditors only indirectly through shareholders' declaration of intent.

9 M. Lutter et al. (see Note 18), p. 242 - DOI: http://dx.doi.org/10.9785/ovs.9783504380236.

20 Of course, substantive thin capitalisation may occur for an 'Ltd' as well; however, because of the lack of formal minimum requirements, one can talk about the liability of a director in this case only when thin capitalisation has turned into permanent insolvency.

21 W.V.H. Rogers. Winfield \& Jolowicz on Tort, 17th ed. Sweet \& Maxwell 2006, p. 344; M. Lunney, K. Oliphant. Tort Law, 2nd ed. Oxford University Press 2003, pp. 563, 581; R.F.V. Heuston, R.A. Buckley. Salmond and Heuston on the Law of Torts, 21st ed. Sweet \& Maxwell 1996, p. $247 \mathrm{ff}$.

22 D.A. Bennett et al. Palmer's Company Law: Annotated Guide to the Companies Act 20o6, 2nd ed. Thomson Reuters 2009, p. 597.

23 F. Steffek. Gläubigerschutz in der Kapitalgesellschaft. ['Protection of the Creditors of a Company'], Mohr Siebeck 2011, pp. 295-296 (in German).

24 The first time the Supreme Court of Estonia recognised the protective nature of the duty to file a bankruptcy petition was in its decision CCSCd 6.5.2003, 3-2-1-45-03, in which the court noted that a director may be held liable to the creditors in exceptional cases, with one of those exceptions perhaps being cases of breach of the duty to file a bankruptcy petition as stipulated in Article $185\left(5^{1}\right)$ of the Commercial Code; in that case, the director may also be held personally liable to the creditors. 
Estonian judicial practice with respect to this issue has been changeable and uncertain. For example, Harju County Court has declared the provision that stipulates the duty to call a general meeting in the event of thin capitalisation of a company a protective provision by noting that the purpose of keeping an eye on the net assets is, among other things, to protect the creditors of the private limited company in a situation wherein the activities of the debtor company are continued on the basis of loan capital (basically, at the expense of creditors), which may, in turn, decrease the prospects of creditors to have their claims satisfied'.* ${ }^{2} 5$

However, in a later decision, Tallinn Circuit Court was not so sure when regarding the matter and, instead, sent the dispute back to the county court for a new hearing, instructing the lower court that, for a creditor's claim to be satisfied on the basis of $§ 171$ of the Estonian Commercial Code, it would be necessary to establish first whether protection of the company's creditor from damage is the purpose of this provision at all. ${ }^{*} 26$

This author thinks that whether a provision is considered to be a protective one should be clear and foreseeable. Vagueness and incomprehensibility of protection-aimed provisions creates insecurities for directors and damages the spirit of entrepreneurship; at the same time, the preventive function of a protective provision is lost just as much if the consequences of its violation cannot be understood unambiguously. ${ }^{*} 27$

Therefore, the author finds that the provision that imposes a duty on the directors to call a general meeting has not been prescribed for the protection of creditors and, therefore, the creditors cannot have a direct tortious claim against directors when said duty is violated. It is possible to conclude from the latter reasoning that failure to call a general meeting in a case of thin capitalisation of a company does not in itself constitute grounds for the creditors to file a tortious claim against the relevant director.

\section{What prerequisites there might be for personal liability of a director to creditors in cases of thin capitalisation}

Unlike German, English, and Estonian law, Spanish law has stipulated exceptionally strict duties for the director in the event that cause for the termination of a company emerges in a pre-insolvency situation. The purpose of these duties is to avoid deepening of the economic problems of a company that is still solvent but that one can presume is going to become bankrupt soon and, through this, help to protect the company's creditors. Justification for the strictness of the relevant regulation has been offered in the fact that if the company is terminated in due course, then it should be reasonably possible to guarantee full satisfaction of the claims of all creditors during liquidation; new creditors will not enter contractual relationships with the company that has terminated its activities; and it will be beneficial for the business environment as a whole if unsustainable companies are removed from circulation in a timely manner. ${ }^{*} 8$

Special regulation has been stipulated in Article 367 of the Spanish Companies Act for the protection of creditors with whom a director enters into a debt relationship after the arising of cause for termination. Among others, one of the causes for termination may be thin capitalisation of a company. The primary obligation of a director in this context is to recognise the presence of cause for termination in a timely fashion. ${ }^{* 2}$ After that point, the director is obliged to call a general meeting within two months' time, so that the general meeting can decide upon application of measures for purposes of eliminating the causes

25 Judgement of the Harju County Court of 30.10.2008, 2-07-46119. A similar position has been expressed by the Tartu County Court, in a judgement of 23.10.2007, 2-07-13801.

26 Judgement of the Tallinn Circuit Court of 21.12.2010, 2-09-44968. It may be correct to assume that the dispute referred to this court was settled in a compromise since the proceedings have been terminated; no final decision on the substance of the case has been made.

27 See also: F. Steffek (Note 24), p. 548.

28 J. Valenzuela Garach. La responsabilidad de los administradores en disolución y en el concurso de las sociedades capitalistas. ['The liability of a director in the cource of dissolution and bankruptcy of a company'], Marcial Pons 2007, p. 31 ff. (in Spanish).

29 G. Guerra Martín et al. La responsabilidad de los administradores de sociedades de capital, ['Liability of a director of a company'], 1st ed. Wolters Kluwer España 2011, p. 229 (in Spanish). 
for eventual termination or initiating bankruptcy proceeding when the company's ultimate insolvency has become evident or it has been decided to terminate the company's activities altogether.

From that moment in proceedings, there is a considerable difference between Spain and the other countries analysed in the article. If the general meeting refuses to take appropriate decisions or the meeting does not take place at all, the director in the Spanish system is still obliged to file an application for dissolution of the company (or a bankruptcy petition, if needed) before the statutory deadline. Even if the general meeting takes a decision not to terminate the activities of the company when causes for termination objectively have arisen and does not eliminate those causes either, the director still remains under the obligation to fulfil his abovementioned duty. ${ }^{*} 30$ As can be seen from the foregoing discussion, the director of a company that experiences thin capitalisation does not have a corresponding duty under German, English, or Estonian law unless the company has already become permanently insolvent.

When the previously mentioned duties are violated (i.e., delaying the calling of a general meeting or failing to call a general meeting or to file a bankruptcy petition or application for dissolution of the company), then in Spain the directors are held solidarily liable together with the company ${ }^{*} 31$ for all obligations arising after the coming into being of causes for termination. ${ }^{*}{ }^{32}$

In cases wherein the previously mentioned basis for termination exists, the burden of proof lies with the creditor who files a claim against the director. When thin capitalisation forms the basis for termination, evidence does not cause many problems, since thin capitalisation should be identifiable from accounting records (provided that no accounting requirements have been violated, which violation could constitute a separate basis for a claim against the director). When assessing the starting point of the director's liability, one should proceed from the assumption that it is the moment when it had to be evident to the director that the company's capital no longer was meeting the requirements of the law, not the time at which the corresponding financial statement was prepared. ${ }^{*} 3$

The extent of a director's liability based on Article 367 of the Spanish Companies Act depends on the nature of this liability. If one takes the stance that it is a tortious liability, the management board can only be held liable for damage caused to a specific creditor and that has a causal link with failure to file an application for termination of the company. However, in Spanish legal theory and practice, it has been found primarily that it involves a so-called civil sanction ('sanción civil' in Spanish) for failing to fulfil the duty stipulated by law. ${ }^{*} 4$ The Spanish Supreme Court has repeatedly stated that the liability of a director is objective and that for it to come about, it is necessary only to ascertain that the director failed to act when grounds for termination appeared. It is not even required to prove the existence of a causal link between the behaviour of the management board and the damage that is subject to compensation; even determining the extent of the damage is irrelevant, as the director's breach creates formal solidary liability for the company's debts. ${ }^{*} 35$ This entails exceptionally far-reaching liability of the director for all claims of the company's creditors that emerge after cause for termination becomes evident. The law does not set limits as to the legal origin of creditors' claims either; accordingly, the director must, for example, be held solidarily liable for the company's obligations arising from labour law and tortious relationships equally. ${ }^{*} 6$

The discussion above leads to a question as to the purposefulness of the regulation stipulated in Article 367 of the Spanish Companies Act. Failure to fulfil the obligations described above can surely cause the economic state of a company to deteriorate and indirectly harm the interests of creditors; however, the

$30 \quad$ Ibid., p. 238.

31 There is an 'imperfect' solidary obligation where in an internal relationship the director has the right to demand restitution from the company for the whole amount he has paid; however, if the company covers the debt of a third party, the company will not have the right of recourse to the director.

32 For more information on the liability of the director for violation of Article 367 of the Spanish Companies Act, see A. Moya Jiménez. Disolución, liquidación y transformación de sociedades de capital, ['Dissolution, winding up and reorganisation of a company'], 2nd ed. Bosch 2011, p. 109ff.; À. Rojo, E. Beltrán. Comentario de la ley de sociedades de capital, ['Commentary of the Companies Act'], Vol. 2. Thomson Reuters 2011, p. 2572 ff. (in Spanish).

33 M. Viñuelas Sanz. Responsabilidad por obligaciones sociales y responsabilidad concursal. ['Liability for the obligations of a company and for wrongful tradin], Tirant lo Blanch 2011, p. 35 (in Spanish).

34 A. Rojo, E. Beltrán (see Note 33), p. 2575ff.

35 For example, STS 3900/2010, 30.6.2010. Decisions of the Spanish Supreme Court can be found via the Web page http:// www.poderjudicial.es/search/index.jsp (in Spanish).

36 G. Guerra Martín et al. (see Note 30), p. 267. 
regulation at issue holds the director even more extensively liable for failure to act in the event of thin capitalisation of a company than for not filing a bankruptcy petition for an insolvent company. ${ }^{*} 37$

Although Spanish law establishes civil liability of the director for breaching his duties in a case of thin capitalisation of a company, the Spanish regulation is exceptionally strict and is probably not the best model. Therefore, what might be reasonable limits of directors' liability in the case of thin capitalisation of a company shall be analysed next.

\section{Options for regulating the liability of a director de lege ferenda in a case of thin capitalisation}

It has become clear from the above analysis that differences exist in the regulations valid in the European judicial area with respect to the liability of a director in the case of thin capitalisation of a company. These differences themselves may add to any grounds for 'forum shopping'.

Under German, English, and Estonian law, the director has no personal civil liability to creditors when violating the duty to call a general meeting in the event of thin capitalisation of the relevant company. Simply the existence of the duty to call a general meeting is not enough for application of personal liability of a director; an additional duty related to termination of the company and its economic activities should be stipulated for helping avoid a further decrease in the net assets of the company, as is done in Spain.

Should the general meeting not take action or should it be that it is not possible to execute the decision of the general meeting on continuing the economic activities of the company, an additional duty to liquidate the company could be imposed on the director, as again has been done in Spain. A frequent reason for assetless bankruptcy is the fact that liquidation of the company does not commence in a timely fashion; instead, economic activities are continued until all assets of the company are depleted. Suspension of activities and starting of liquidation proceedings for a company experiencing solvency problems at an earlier stage is in the best interests of the creditors. According to the law currently in force in Germany, England, and Estonia, the director has fulfilled his duties in the manner required once having called the general meeting after becoming aware of the thin capitalisation of the company. If the general meeting does not decide to obtain additional funds or commence liquidation proceedings, the activities of the company are more often than not continued until the company becomes permanently insolvent and, further, completely devoid of assets. This problem is especially apparent with one-person companies, in which notification of a general meeting has no real meaning (the director, who is also the sole shareholder, has fulfilled his duties in the case of thin capitalisation of the company simply by informing him- or herself).

If, in a parallel to Spanish law, the director were to have a statutory obligation to terminate the company experiencing thin capitalisation, this obligation could also be sanctioned under civil law. Whether the civil liability for violating the above-mentioned obligation should be as strict as in Spain is another matter. Punitive liability of a director to creditors (as seen in Spain) should make it easy to file claims against the director; however, it may at the same time bring the threat of a floodgate effect, ${ }^{*}{ }^{*}$ which will encroach on the breadth of the director's entrepreneurship and could, all in all, cause more harm to the business environment as a whole through a decrease in economic activity than there would be benefit arising from better protection of creditors' interests.

The author finds that when a basis for termination of a company arises, liability based on causal connection (i.e., not a sanctional liability) could be implemented for the director who fails to fulfil his duties similarly to liability of a director who violates his duties in the event of the company having become insolvent, with the exception that the point at which the director's liability begins would be earlier in the case of thin

37 In a contrast to when a director is held liable in a case of thin capitalisation of a company, it is not considered possible to hold the director liable on the basis of Article 172 bis (1) of the Spanish Insolvency Act if no causal link exists between the violation by the director and the extent of the claims not paid to the creditors. See: F.M. de la Bárcena. La acción individual de responsabilidad frente los administradores de sociades de capital (art 135 LSA). Individual claim against a director of a company, Article 135 of the Companies Act'], Marcial Pons 2005, p. 375 ff. (in Spanish); see also: F.M. de la Bárcena, Reformas en materia de calificación concursal. - Revista de derecho concursal y paraconcursal 2012.

38 For discussion of how to keep liability law within reasonable limits, see J. Spier (ed.). The Limits of Liability: Keeping the Floodgates Shut. Kluwer Law International 1996. 
capitalisation of the company. ${ }^{*} 9$ If the director were to breach the duty to terminate the company, he would be held liable for damage caused to creditors in consequence of the decrease in net assets after the violation. If, however, the director were to continue the company's economic activities and enter into new debt relationships, with new creditors, he would be held liable for compensation for those new debt obligations as reliance damage instead, as those debt relationships and the accompanying reliance damage would not have arisen at all if the company had been terminated in due course. If the company manages to satisfy all of the creditors' claims regardless of the thin capitalisation or is able to reach a compromise with the creditors on reorganisation of the company, the director's liability would lapse because of absence of damage.

\section{Conclusions}

The legal systems of the countries analysed here differ in their solutions for duties of directors and the corresponding liability in the event of thin capitalisation of a company. In German, English, and Estonian law, the duty of a director is limited to simply calling a general meeting in the case of thin capitalisation. Creditors filing a direct tortious claim against the director in the situation in question is, in essence, precluded.

According to Spanish law, the director has an obligation to terminate the company in addition to the duty to call a general meeting in the case of its thin capitalisation. If the director violates that obligation, he is held very strictly personally liable to the creditors even if there is no causal link connecting the breach, the damage caused, and the extent of the damage.

On the basis of the comparative analysis of German, English, Estonian, and Spanish law, the author offers a hypothetical solution for the regulation of personal tortious liability of a director if the director remains inactive after thin capitalisation of the company. With the hypothetical solution, if the general meeting fails to adopt any decision or the decisions of the general meeting do not enable sustainable continuation of the company's activities, a duty to terminate the company experiencing thin capitalisation should be imposed on the director. If this termination obligation is violated, the director would then be held liable for compensation of quota damage and/or reliance damage caused to creditors in an analogue to a director's liability for harming the interests of creditors in the case of a company's insolvency; the two diverge in that the moment the director's liability begins would be sometime prior to insolvency in the case of violation of the obligation to terminate the company.

39 In Germany, Spain, and Estonia, the director who fails to file a bankruptcy petition in a timely fashion shall be held liable for compensation of the creditors' quota damage (in German, Quotenschaden) to the extent to which the capital of the company has decreased in proportional terms, from the moment when the violation becomes evident. In English law, a director's liability for wrongful trading as stipulated in the Insolvency Act 1986 (in Article 214) enables reaching of a similar result. In addition, German law recognises the additional possibility of filing for reliance damages (in German, Vertrauensschaden) claim against the director if he conceals the company's insolvency from the creditor and concludes a new debt relationship that, in light of the company's insolvency, should not have been entered into. Application of a reliance damage claim filed by new creditors is a matter of debate in Estonia and in Spain; courts in England have denied the latter option. On personal liability of directors for damaging the interests of creditors in a situation of insolvency in the countries considered here, see D. Möritz. Haftung des Managements und Drittschutz. ['Liability of the Management and Protection of Creditors'], Nomos 2011 (in German); P. Loose et al. The Company Director: Powers, Duties and Liabilities, 11th ed. Jordans 2011; J.M. Rodríguez. Conductas de los administradores que generan responsabilidad concursal. ['Liability generating Behavior of a Director'] - Daniel Vítolo (ed.). Derecho de sociedades y concurso. Cuestiones de actualidad en un entorno de crisis. ['Company Law and Bankruptcy. Current Issues in a Crisis Environment'], Comares 2011 (in Spanish). 